\title{
Interpretacje
}

\section{Blanchot: Trzecie między zaimkami}

Wojciech Kalaga

TEKSTY DRUGIE 2018, NR 4, S. 310-332

DOI: $10.18318 /$ td.2018.4.19

yśl, która nie może pomieścić się w świecie dwoistości, która wymyka się ograniczeniom opozycji, tworzy własne przestrzenie, by ostatecznie skupić je w jakimś emblematycznym (nie-)pojęciu lub (nie-)słowie. W filozofii Derridy takim emblematem jest différance i caly krąg terminów ją otaczających, z niej się wywodzących, do niej prowadzących lub przez nią czytanych; w myśli Maurice'a Blanchota rolę taką pełni le neutre, neuter, neutralne, nijakie, le „il”, to. W języku francuskim neutrum - jako rodzaj gramatyczny - nie występuje; gdyby zatem ograniczyć się jedynie do wąskiej perspektywy językowej, należałoby uznać, że pisze Blanchot o czymś, czego nie ma. Jednak, jak powiada Blanchot w L'Entretien infini, „neuter nie jest jedynie kwestią słownictwa" (IC, 298)' . W istocie ta językowa

1 We wszystkich przytoczeniach z L'Entretien infini i Le pas au-delà W tekście posługuję się wersjami angielskimi, odpowiednio: Infinite conversation (skrót IC) oraz The step not beyond (skrót SNB). M. Blanchot The infinite conversation [L'Entretien infini, 1969], transl. S. Hanson, University of Minnesota Press, Minneapolis-London 1993; M. Blanchot The step not beyond [Le pas au-delà, 1973], transl. L. Nelson, State University of New York Press, Albany 1992.

\author{
Wojciech Kalaga \\ - emerytowany \\ profesor teorii \\ literatury i literatury \\ angielskiej. Prowadził \\ badania i wykładał \\ m.in. w uniwersyte- \\ tach Yale, Mann- \\ heim, Queensland, \\ Tarragona i Murdoch, \\ gdzie kierował \\ zakładem English \\ and Comparative \\ Literature. Edytor serii \\ Literary and Cultural \\ Theory w Lang Verlag, \\ redaktor naczelny pe- \\ riodyku Er(r)go: Teoria \\ - Literatura-Kultura, \\ wiceprzewodniczący \\ KNoL PAN. Kontakt: \\ w.kalaga@poczta. \\ onet.pl
}


nieobecność ${ }^{2}$ pozwala wyraziściej umocować neuter jako pojęcie filozoficzne czy intelektualne. Neuter nie jest zatem trzecim rodzajem gramatycznym, do którego należałaby „określona klasa istnień lub bytów” (IC, 299). Neuter nie pozwala się przypisać żadnemu rodzajowi; jest czymś „nie-ogólnym, nie-rodzajowym i nie-konkretnym" - jest Trzecim sytuującym się w sferze między: między mówieniem a pisaniem, między tożsamym a innym, między bliskim a dalekim, między obecnością a nieobecnością, między życiem a śmiercią.

\section{Neutralne}

Aby mówić o neuter, trzeba dać mu nazwę: „Neuter można nazwać, ponieważ jest nazwane (choć to nie stanowi dowodu)" (SNB, 83). Nazwanie neuter nie oznacza jednak poddania go logosowi; wprawdzie nazwa mu nadana oznacza przede wszystkim "pragnienie zdominowania neuter" (SNB, 83), ono jednak wymyka się, ,jest obce wszelkiej dominacji” (SNB, 83). Neuter, ,nazwa bez nazwy" (SNB, 118), ,nic więcej niż słowo” (SNB, 5), „słowo zbyteczne” (IC, 312; SNB, 5, 6, 59), „słowo w nadmiarze” (SNB, 5), „słowo nadwyżka” (SNB, 59) jest „implikowane” w działaniu każdego języka, jest obecne w języku, przesyca go, ,jak gdyby język «ogólnie» był neuter” (SNB, 73). Nazwanie neuter („moc nazwania neuter, która zawsze była mocą nie nazwania go"; SNB, 83) oznacza jednocześnie poddanie mu całego języka, ,wszystkiego, co w języku widoczne i niewidoczne" (SNB, 83). Jeden z fragmentów Le pas au-delà - krótki równoważnik zdania - ogarnia w swej zwięzłości wszelkie językowe zakamarki: "Zaszczepiony w każdym słowie: neuter" (SNB, 84).

Wpisując neuter w działanie języka, Blanchot podważa „archaiczną konieczność binarnego w istocie czytania (jak gdyby wszystko musiało zaczynać się od dwóch)", podważa binarność, która „traci swą dwoistą wartość i pluralizuje się do punktu nieokreśloności" (SNB, 74). To kwestionowanie binarności nie ma jednak charakteru produktywnego ruchu Heglowskiego zniesienia; jest raczej w sposób aporetyczny między niż w syntezie ponad:

Neuter, paradoksalna nazwa: prawie nie mówi, jest słowem niemym, prostym, a jednak zawsze okrywa się zasłoną, zawsze przemieszcza się

2 Ponieważ w języku francuskim brak rodzaju nijakiego, neutrum, Blanchot używa frazy le "il", która jest połączeniem trzecioosobowego zaimka męskiego i trzecioosobowego zaimka nieosobowego; autorka przekładu angielskiego tłumaczy tę frazę jako "he/it”. W polskim tekście używam zaimka nijakiego "to", neutrum, oraz odpowiednio terminów: neuter, neutralne raczej niż „nijakie"(które ma konotacje negatywne). 
poza swe znaczenie, niewidocznie się rozwija, nie zaprzestając rozwikływania w bezruchu swego położenia, które odrzuca głębię. Neutralizuje, neutralizuje (siebie), przypominając w tym (ale nie więcej niż przypominając) ruch Aufhebung, ale o tyle o ile zawiesza [znosi] i zachowuje, zachowuje jedynie ruch zawieszania [znoszenia], to znaczy dystans, który tworzy przez fakt, iż zajmując teren, powoduje zanikanie dystansu. Neuter zatem oznacza różnicę w bez-różnicy i obojętności [difference in indifference], mętność w przezroczystości, negatywne skandowanie innego, który może odtwarzać się tylko przez odrzucone, tj. pominięte, przyciąganie tożsamego [one]. (SNB, 75)

Negacja binarności i jednocześnie aporetyczna Trzeciość neuter (le neutre), obecna już - i uśpiona - w greckim źródłosłowie ne-uter, wydobyta zostaje i wyeksponowana przez Blanchota: „Neuter w najprostszy sposób wywodzi się z negacji dwóch terminów: neuter, ani jeden ani drugi" (SNB, 74). W odpowiedzi na pytanie, które z góry zakłada binarny obraz świata - „dzielenie na dwa" (SNB, 77) - neuter odrzuca wybór, odrzuca samą możliwość wyboru między dwoma terminami, między jednym a drugim: „«Który z dwóch?» «Ani jeden ani drugi»" (SNB, 77). Czyniąc neuter jedną z najważniejszych kategorii swego „pisania”, budząc aporię w nim uśpioną, Blanchot zaszczepia ją językowi opartemu na klarownej różnicy między tożsamym a innym: neuter "rozprasza mowę tożsamego" (SNB, 109), rozprasza się w języku, kierując naszą uwagę tam, gdzie „ukrywa się w ukrywaniu i ukrywa nawet akt ukrywania, gdzie nic, co znika w ten sposób, nie pojawia się, efekt zredukowany do nie-efektu; neuter, w artykulacji widzialnego-niewidzialnego [...]" (SNB, 77).

Nietrudno dostrzec, że neuter niesie sobą tajemnicę, którą niby chce złagodzić, ale która nieodmiennie mu towarzyszy: „Tajemnica neuter, tajemnica, którą neuter pomniejsza, nawet kiedy powoduje, że prześwieca ona w nazwie" (SNB, 59). Trudno dotknąć tej tajemnicy już u jej samego początku - nieuchwytna, aporetyczna ontologia neuter zawiesza się gdzieś między istnieniem i nieistnieniem, między zapowiedzią a zaprzeczeniem, powstawaniem a zanikaniem: „neuter wygasa zanim się wytworzy” (SNB, 68), a jednak kusi nas swą "negatywną obecnością" (SNB, 69). Nie odsłonimy całkowicie tajemnicy neuter; bowiem zaprzeczylibyśmy w ten sposób jego naturze - to, co zostałoby odsłonięte, nie byłoby już tym, co chcieliśmy odsłonić; nie odsłania jej zresztą do końca sam Blanchot. Pyta: „Ale czym jest neuter, neutralne?” (IC, 298), jednak nigdy nie daje ostatecznej odpowiedzi, bo odpowiedź taka unicestwiłaby swój przedmiot, czyniąc go właśnie przedmiotem. Neuter zaś nie jest ani 
przedmiotem ani podmiotem: „W tej samej mierze odmawia przynależności do kategorii podmiotu, jak do kategorii przedmiotu"3 (IC, 299).Zawsze jednak - i fraza ta pojawia się kilkakrotnie w Le pas au-delà - „zawsze możemy zastanawiać się nad [dopytywać o] neuter" (SNB, 69, 109), wiedząc przy tym, że „dociekanie nie wyjdzie poza dociekanie [...] ponieważ neuter zawsze wchodzi w rachubę, która nie wchodzi w rachubę"4 (SNB, 109). Nie wchodzi zatem w rachubę ostateczna "prawda neuter" czy „wiedza o neuter" (SNB, 87); neuter „nazywa coś, co wymyka się wszelkiemu nazywaniu” (SNB, 72):

Neutralne zawsze jest gdzie indziej niż tam, gdzie chcielibyśmy je usytuować; nie jest po prostu zawsze po tej stronie i zawsze ponad neutralnym, nie jest po prostu pozbawione właściwego znaczenia i nawet jakiejkolwiek formy pozytywności i negatywności, ale powstrzymuje też obecność lub nieobecność przed poddaniem go z pewnością jakiemukolwiek doświadczeniu, nawet doświadczeniu myśli. (IC, 305-306)

Neuter zawsze pozostaje Trzecim między - „entre: entre ne(u)tre”.

Strategię Blanchota trafnie ujmują słowa Leslie Hilla, który odnosi je wprawdzie do Blanchotowskiej lektury Nietzschego, ale które zachowują szczególną adekwatność w odniesieniu do neuter:

Podejście [Blanchota] jest nie tyle hermeneutyczne, co hiperboliczne, zaś jego celem jest doprowadzenie stwierdzeń Nietzschego do granic, to tego ekstremalnego punktu, w którym odsłonięte zostaje coś innego niż regularność pojęcia, inność, która wymyka się pojęciowemu wyjaśnieniu, i która może zostać wpisana jedynie przez logikę suplementarności, to znaczy logikę zarówno odejmowania, jak i dodawania, wedle której każda wypowiedź, dzięki fragmentarycznemu, zanim zostanie potwierdzona jest już wycofana, w ten sposób, że wycofanie ukazuje się odtąd

3 Por.: „I nie znaczy to po prostu, że jest ciągle nieokreślone, jak gdyby wahało się między jednym a drugim, ale raczej, że neuter zakłada inną relację, niezależną ani od obiektywnych warunków, ani od subiektywnych inklinacji" (IC, 299).

4 " [...] because the neuter always comes into question that is out of the question" (SNB, 109).

5 Jak wskazuje angielska tłumaczka Le pas au-delà, w tej wielostronnej grze słów entre jest imperatywną formą "wejść" i jednocześnie przysłówkiem "między". N’etre jest negatywną formą "być" (czyli tutaj: „nie być"), a po wstawieniu (u) staje się neutre czyli „neuter" (SNB, 138). 
jako rodzaj potwierdzenia, a potwierdzenie jako rodzaj wycofania, gdzie jedno wymazuje drugie lub nad nim się nadpisuje w nieustającym ruchu rozproszenia. Taka logika nie ma odpowiedniej nazwy i dlatego może otrzymać, przynajmniej tymczasowo, skromny, bezpretensjonalny tytuł neuter, neuter, które nie ma centrum, jedności czy tożsamości, ale które pomimo to, przekraczając pozytywne w równej mierze jak negatywne, nie może nie zostać potwierdzone [affirmed], które mówi w języku, ale nie jest tożsame z jakimkolwiek pojedynczym słowem, wyrażeniem lub pojęciem, ponieważ poprzedza ono i przewyższa wszystkie dostępne terminy, które wydrąża, przemieszcza i od-znacza [re-marks]. ${ }^{6}$

Ta logika jednoczesnego dodawania i odejmowania wizualnie materializuje się, jak za chwilę zobaczymy, w L'Entretien infini w postaci arytmetycznych symboli + i - postawionych jeden nad drugim, podwojonych i poprzedzających każdy fragment drukowany kursywą, ale też niewidzialnie i niematerialnie panuje w całym dyskursie Blanchota. Skoro jednak logika neuter nie ma nazwy, nie pozwala się ulokować w pojęciowej przestrzeni logosu, pozostaje nam nie tyle odsłonić jej tajemnicę, co zbliżać się do niej, przemieszczając się przez najważniejsze jej obszary: nieznane, fragmentaryczne i pisanie.

\section{Nieznane}

Nieznane może przybliżyć nas do neuter, bowiem „doświadczenie neutralnego implikowane jest w każdej relacji z nieznanym [...] Nieznane jest neutralne, jest neuter" i, podobnie jak neuter, "nie jest ani przedmiotem ani podmiotem" (IC, 299-300).Widzimy już, że - podążając za Blanchotem - należy nieznane rozumieć w sposób szczególny. Nieznane nie jest tutaj czymś, co jeszcze nie jest znane, ale co przyszła wiedza może nam przynieść, ani też czymś „absolutnie niepoznawalnym” (IC, 300), pozostającym w sferze transcendencji. Nie chodzi więc o odkrycie jeszcze nieznanego i wprowadzenie go - jako już znanego - w sferę wiedzy, ani o mistyczne próby zbliżania się do niepoznawalnego. W poszukiwaniach, których głównym obszarem jest myśl i poezja, należy skierować się na „nieznane jako nieznane” (IC, 300), a inaczej, odkryć nieznane w tym jego aspekcie, który je zakrywa i czyni nieznanym. Jest w tym oczywiście paradoks czy sprzeczność właściwa myśli Blanchota:

6 L. Hill Maurice Blanchot and Fragmentary Writing. A Change of Epoch, Continuum, London-New York 2012, s. 36. 
mamy ujawnić coś, nie odsłaniając zasłony, a przeciwnie, eksponując zasłonę jako meritum nieznanego: „Ta relacja musi pozostawić nienaruszonym - nietkniętym - to, co wyraża i nie odsłaniać tego, co ujawnia. Ta relacja nie będzie polegała na odsłanianiu. Nieznane nie zostanie wyjawione a wskazane" (IC, 300); wskazane, dodajmy, właśnie w swym „nieznaniu”. Blanchot nazywa ją "relacją nie-obecności, która nie byłaby odkrywaniem” (IC, 300).

Zgłębianie neuter pod postacią nieznanego nie jest jednak tylko próbą cząstkowego, przyczynkowego badania wycinka języka czy myśli; zamiar Blanchota sięga znacznie dalej, zaś celem jest podanie w wątpliwość „postulatu, który dominuje całą myśl Zachodu" (IC, 301): wiedzy opartej na opozycji widzialne-niewidzialne, metafor światła i ciemności jako podstawy myśli kierującej się ku swym przedmiotom, poddaniu wszelkiej wiedzy, rozumienia i wszelkich relacji perspektywie całości. Neuter, tu jako nieznane, które nie jest ani przedmiotem wiedzy obiektywnej ani mistycznej intuicji, wymyka się więzom tego postulatu. Po pierwsze nie poddaje się prawu całości: „Nieznane jako neutralne zakłada relację, która obca jest jakiemukolwiek przymusowi tożsamości, jedności, nawet obecności" (IC, 300). Po wtóre, nie przynależy do metaforyki światła lub jego braku, ani też nie mieści się w ramach dychotomii widzialne-niewidzialne: „Nieznane nie jawi się spojrzeniu, nie jest też jednak przed nim ukryte: ani nie jest widzialne ani niewidzialne; lub, dokładniej, odwraca się od wszelkiego widzialnego i wszelkiego niewidzialnego" (IC, 300) i czyni to „w kategoriach, które nie odpowiadają żadnej możliwości” (IC, 301).

Jako neuter, nieznane nie jest więc sprawą przyszłości, „prostego nieznanego", które byłoby zaledwie „jeszcze nieznanym”; nie poddaje się żadnej perspektywie: „nie pozostaje w zasięgu wzroku, nie może należeć do całości”, wymyka się i negacji i afirmacji, „nie jest ani negatywne ani pozytywne” (IC, 301). Dyskurs - mówienie, pisanie - który ujmuje nieznane jako neuter, musi być szczególnego rodzaju dyskursem, który nie rości sobie prawa, by ogarnąć i przyswoić swój przedmiot, by niejako w akcie wypowiadania brać go w niewolę: „Wypowiadać nieznane, przyjmować je przez mowę, pozostawiając nieznanym, znaczy dokładnie nie zawładnąć nim, nie pojmować go [comprehend] [...] podjąć odpowiedzialność mowy, która mówi, nie stosując żadnej formy władzy. Nieznane, jako nieznane, jest tym nieskończonym, a mowa, która je wypowiada, jest mową nieskończonego" (IC, 302).

Nieskończoność mówienia o nueter jako nieznanym odnosi się też do neuter w sensie ogólniejszym, które Blanchot zgłębia w pisanych kursywą dialogicznych „Nawiasach” następujących po rozdziale o nieznanym u René Chara. Owe „Nawiasy” wymagają jednak swoistej lektury. Każda wypowiedź dialogu, 
jak wspominałem, poprzedzona jest znakami arytmetycznymi - dwoma minusami oraz umieszczonymi nad nimi dwoma plusami $( \pm \pm)$ - które zdają się podwójnie podawać w wątpliwość jednoznaczność i afirmatywność tych wypowiedzi, jak w poniższym cytacie:

\pm \pm Tak więc-być może - lepiej określiliśmy prowokację neutralnego. Neutralne: o jedno słowo za wiele, które wycofuje się albo rezerwując sobie miejsce, w którym zawsze go brakuje, choć caty czas tam się zaznacza, albo prowokując przemiejscowienie [displacement], które jest bez miejsca, albo na wiele sposobów rozmieszcza sięjako suplement miejsca. (IC, 312)

Neuter pojawia się tu w przestrzeni Trzeciego - między afirmacją (plus) i negacją (minus) - która utwierdza jego własną Trzeciość. Stąd zapewne na pytanie „Co mamy rozumieć przez to słowo?" uczestnik dialogu odpowiada: „Być może nie ma w nim nic do rozumienia” (IC, 303). Nie chodzi tutaj rzecz jasna o prostotę i oczywistość słowa, a raczej o to, że władza rozumienia nie jest tu odpowiednim narzędziem do zastosowania. I rzeczywiście, lektura całego dialogu nie przynosi nam zrozumienia neuter w konwencjonalnym znaczeniu „rozumienia”, a jedynie przybliża jego sens/nie-sens w akcie, który sytuuje się gdzieś między rozumieniem i nie-rozumieniem, doświadczeniem i nie-doświadczeniem. Owo przybliżanie polega na wymazywaniu i eliminacji, swego rodzaju fenomenologicznej redukcji, która - nie mówiąc wprost, czym neuter jest - zdejmuje zeń warstwy tego, czym nie jest.

Owa nieskończoność neuter przejawia się w ruchu znaczenia, przywodzącym skojarzenia z Derrideańską dyseminacją i nieskończoną semiozą Peirce'a w połączeniu z fenomenologiczną époché: „znaczenie operuje czy działa przez ruch wycofywania się, który w pewnym sensie nie ma końca [...] samo znaczenie może nieść znaczenie jedynie umieszczając siebie w nawiasie lub cudzystowie i czyniąc to przez nieskończona redukcję" (IC, 304). W ten sposób, jak wynika z dialogu, znaczenie istniałoby jedynie w charakterze neutralnego, przy czym owo neutralne musiałoby być obce znaczeniu, „nie obojętne, a nawiedzajace możliwość znaczenia i nie-sensu przez niewidzialny margines różnicy" (IC, 304). Polegałoby to na nieskończonym dążeniu do époché, nieustannego zawieszania, nawet zawieszania samej siebie, jak czyni to fenomenologia i niekiedy literatura?

7 „Neutralnym byłby akt literacki, który nie należy ani do afirmacji ani do negacji, i który (w pierwszej fazie) uwalnia znaczenie jako fantom, nawiedzenie, symulakrum znaczenia; jak gdyby literatura z natury była widmowa, nie dlatego, iż byłaby nawiedzana przez samą siebie, ale dlatego, że niesie 
Znaczenie, które wyłania się z tego procesu redukcji czy wycofywania się nie jest znaczeniem stabilnym w rozumieniu jakiejkolwiek semantyki, ale nie jest też niedostrzegalne - jawi się jedynie jako ulotne mgnienie:

"[...] w pewnym sensie, znaczenie, które pojawia się przelotnie, nigdy nie uobecniając sie, ale też nie znikając, pasywne i jak gdyby nie ulegające przedawnieniu, a jednak pozbawione $i$ wolne od jakiegokolwiek właściwego znaczenia, ponieważ przekazuje ono znaczenie przez modalności, które jako jedyne nadają mu wartość, rzeczywistośc, 'sens"'. - Tak więc znaczenie znaczenia byłoby neuter, neutralne?" - „Przyjmijmy na moment co następuje: neutralne, jeżeli już zarówno a firmacja jak inegacja pozostawia je nietknięte wjego pozycji znaczenia (Lublepiej:powiedzmy, że znaczenie nie jest stanowione, ani pozytywnie ani negatywnie, ale samo się potwierdza [affirm],jak gdyby poza wszelka afirmacją i wszelka negacja). (IC, 303)

Znaczenie neutralne wymaga wycofania się mówiącego/piszącego podmiotu, jego wymazania (do czego jeszcze wrócimy) i jednocześnie wyzbycia się przez samą mowę zaangażowania w to, co wyraża: „[...] ten, kto nie wchodzi w to, co mówi, jest neutralny; tak jak mowę można uznać za neutralna, gdy wypowiada się ona, nie biorac pod uwage ani siebie ani tego, kto ja wypowiada, jak gdyby mówiąc nie mówiła, a pozwalała temu, co nie może zostać powiedziane, mówić w tym, co jest do powiedzenia" (IC, 303). Neuter w sferze znaczenia „działa” w szczególnym stanie pasywności ${ }^{8}$ czy bierności, która „jest ponad, i zawsze ponad, jakąkolwiek strona bierna; pasja jej właściwa, która spowija właściwe jej działanie, działanie w niedziałaniu, efekt nie-efektu" (IC, 305). W rezultacie jednoczesnego działania redukcji i pasywności, jeżeli można użyć takiego oksymoronu, znaczenie jako neuter - podobnie jak nieznane - wymyka się więzom tożsamości, którą dałoby się określić choćby przez różnicę:

ona wstępny warunek wszelkiego znaczenia, co jest jej obsesją. Lub prościej, ponieważ sama zostałaby zredukowana do angażowania się w nic innego, jak tylko redukcję redukcji, fenomenologicznej lub nie [...]" (IC, 304).

8 Niezwykle trafnie ujął ten szczególny rodzaj radykalnej pasywności, również w odniesieniu do podmiotu, Thomas Carl Wall: „[...] pasywność w radykalnym sensie, zanim jeszcze po prostu przeciwstawia się aktywności, jest pasywna względem siebie samej i w ten sposób poddaje się sobie, jak gdyby była zewnętrzną siłą. Stąd radykalna pasywność ukrywa lub żywi w sobie lub komunikuje się z potentiq; jest zawsze na zewnątrz siebie i jest swoim własnym innym. Pasywna wobec siebie esencjalna pasywność podmiotu musi zaznać siebie, cierpieć siebie, czuć siebie jako innego. W tym sensie pasywność jest czysto pasyjna [passionate]". T.C. Wall Radical Passivity. Levinas, Blanchot, and Agamben, SUNY Press, New York 1999, s. 1. 
\pm \pm Neutralne: to, co doprowadza różnicę [difference] nawet do stanu obojętności [indifference]. Dokładniej to, co nie pozostawia obojętności [indifference] jej ostatecznemu zrównaniu. Neutralne jest zawsze oddzielone od neutralnego przez neutralne i, dalekie od tego by pozwolić się wyjaśnić przez tożsame, pozostaje nieidentyfikowalna nadwyżka. (IC, 305)

Nieznane przybliża nas nieco do neuter, ale nie wyczerpuje jego Trzeciości; nadwyżka zawsze pozostaje niezgłębiona. Potrzebny jest teraz krok dalej, krok we fragmentaryczność, która stanowi formalną i metafizyczną istotę Le pas au-delà. Jeżeli w nieznanym neuter ujawnia się jako Trzecie znaczenia, między jego afirmacją i negacją, to we fragmentarycznym realizuje się jako Trzecie między całością a osobnością, między obecnością i nieobecnością, jako quasi-nieobecność, o której wspomina Blanchot w L'Entretien infini: „Pamiętajmy, że to, co jest neutralne, dane jest w pozycji quasi-nieobecności, jako efekt nie-efektu" (IC, 303). Efektem nie-efektu w przypadku fragmentarycznego jest Trzecie między obecnością i nieobecnością całości (całości książki, całości narracji i opowieści, całości myślowego wywodu); fragmentaryczność zawiesza myśl między totalizującą jednością książki a osobnością i oderwaniem jednego passusu od pozostałych.

\section{Fragmentaryczne}

Fragment, inaczej niż mogłoby to sugerować codzienne użycie tego słowa, nie jest u Blanchota „częścią całości” (SNB, 43), którą uzyskałoby się, gdyby poskładać wszystkie fragmenty razem; pisanie fragmentaryczne, „pisanie w relacji do fragmentarycznego" nie oznacza "pisania fragmentami” (SNB, 42). Z drugiej strony fragmentaryczność - jako rezultat przerwania, pęknięcia czy rozłamu - nie polega na rozbiciu na fragmenty czegoś, co istniało lub istnieć mogłoby jako całość; to jedynie nasz nawyk totalizującego myślenia każe nam postrzegać fragment w kategoriach całości, „integralności substancji" (IC, 307). W istocie, fragment jest fragmentem samym w sobie, bez nadrzędnej totalności; podobnie fragmentaryczność jako tryb pisania nie podlega zasadzie totalizacji.

Istotę fragmentarycznego i jego związek z neuter (jeżeli „pomyśleć fragmentaryczne, pomyśleć je w relacji do neuter, obydwa zdają się wymawiać się razem", jednym tchem; SNB, 42) dostrzegamy w rozważaniach filozofa na temat tych powiązań u René Chara. Poezja Chara, pisze Blanchot, uczy nas, jak w jednym „podwojonym słowie” zjednoczyć i ująć „fragmentaryczne 
neuter - nawet jeśli to podwojenie jest podwójnym podwojeniem tajemnicy" (IC, 307). „Sproszkowany wiersz" Chara (poème pulvérisé) kieruje nas ku doświadczeniu rozproszenia, rozdzielności i nieciągłości, pisze Blanchot, zanim jakakolwiek całość zaistniała lub została założona. Wiersz fragmentaryczny - lub, ogólniej, mowa fragmentaryczna - to nie wiersz lub wypowiedź, której nie udało się pomyślnie osiągnąć zjednoczenia w całość; przeciwnie, ich osiągnięcie polega na kwestionowaniu całości, „na afirmacji nieredukowalnej do jedności" (IC, 308):

Nowy rodzaj porządku nie zawierający harmonii, zgodności czy pojednania, który przyjmuje rozłączność i rozbieżność jako nieskończone centrum, z którego, przez mowę, stworzona ma zostać relacja; porządek, który nie komponuje a zestawia, to znaczy pozostawia każdy z elementów wchodzących w relację na zewnątrz siebie, przestrzegając i zachowując tę zewnętrzność i ten dystans jako zasadę - zawsze już zachwianą [undercut] - wszelkiej sygnifikacji. [...] Porządek na poziomie zamętu. Nieruchome stawanie się. (IC, 308)

Ów „porządek na poziomie zamętu” nie jest jednak niekoherencją, która "choć na odwrót, nazbyt dobrze wie jak komponować i układać rzeczy” (IC, 308). W tym właśnie szczególnym porządku czy „rygorze” fragmentaryczne łączy się z neutralnym.

Słowa, którymi Blanchot opisuje poezję Chara, w równej mierze odnoszą się do jego własnej „mowy”, która pozostaje poza dyskursem rozumianym jako sposób wypowiedzi rządzony prawami racjonalności, wyłączonego środka, klarownych opozycji i przeciwieństw:

popełnilibyśmy błąd, interpretując ten język, jak gdyby nadal należał on do dyskursu, dialektycznego lub nie. Rygorystycznej niespójności, jaką ten język proponuje - chwilami tak trudnej, iż doświadczamy jej jako mowy poniesionej emocjami lub cierpieniem - nie można zmusić, by weszła $\mathrm{w}$ formy starych kategorii (napięcia i rozwiązania przeciwstawnych terminów). Wzywa nas ona do przekroczenia fałszywego zachwytu nad błyskotliwą dwuznacznością, a potem udręki sprzeczności przeciwstawiającej jeden termin drugiemu, ale nie po to, by dotrzeć do totalności, w której za i przeciw zostają pogodzone lub zespalają się ze sobą; raczej czyni nas on [Char] odpowiedzialnymi za nieredukowalną różnicę. (IC, 309) 
Jak obrazuje to dyskurs Blanchota (IC, SNB), fragmentaryczne pozostaje poza porządkiem ruchu od początku do końca, gdzie następstwo jest świadectwem postępu myśli czy narracji, wypływania jednej rzeczy z drugiej, by w rezultacie zamknąć się w strukturze całości. Fragmentaryczne jest "grą granic", która jednak nie wiąże się w żaden sposób z ograniczeniami: „Potrzeba fragmentarycznego: gra granic, w której nie gra żadne ograniczenie; fragmentaryczne, rozłączność granicy i ograniczenia" (SNB, 44).

Tę „bezgraniczność” fragmentaryczności jako emanacji neuter mimetycznie lub raczej metamimetycznie, ilustruje Le pas au-delà. Książka składa się z różnej długości tekstów - czasem jedno- lub kilkuzdaniowych, czasem kilkustronicowych - poprzedzonych w każdym przypadku niewielkim rombem •. Podobnie jak w Nawiasach, w L'Entretien infini, także tutaj stosuje Blanchot, obok zwykłej czcionki, kursywę. Nie należy jednak dać się zwieść temu dychotomicznemu odróżnieniu druku: choć na pierwszy rzut oka mogłoby się wydawać, że fragmenty pisane kursywą mają charakter przetykanej dialogami fikcyjnej opowieści, gdy zaś te pisane zwykłym drukiem wędrują po obszarach filozofii i teorii, to uważniejsza lektura dowodzi, że ten dychotomiczny podział nie jest adekwatny. Należy w tym miejscu zgodzić się z Leslie Hillem, że takie upraszczające, binarne podejście, oznaczałoby „podporządkowanie pisania Le pas au-delà hierarchicznemu autorytetowi pojęcia i narzucenie tekstowi, jawnie lub niejawnie, totalizującej dialektycznej jedności, która pozostaje w sprzeczności z radykalnym rozproszeniem potwierdzanym od początku do końca przez neuter i fragmentaryczne [...] Relacja między dwoma typograficznymi stylami jest złożona, heterogeniczna i często nierozstrzygalna [imponderable]"'. Światy kursywy i zwykłego druku wyłaniające się z fragmentów przesycają się wzajemnie. W obydwu postaciach graficznych pojawiają się wątki filozoficzne, fragmenty dialogów (ujęte w cudzysłowy i w kursywie, i w zwykłym druku), myślowe deliberacje, passusy narracyjne, w których pojawia się „on”, zaimek bez jasnego w tekście odniesienia, rozproszony podobnie jak fragmenty. Mamy tu raczej do czynienia z wielorakim przenikaniem się i otwieraniem coraz to nowych dyskursów, grą suplementów, które to wiążą się ze sobą, to rozdzielają, nie podlegając żadnej totalizującej hierarchii. A jednak, choć fragmenty są odrębne, nie tylko oddzielone białą przestrzenią kartki, ale i nie połączone w ciągłość filozoficznego wywodu czy narracji - nie stanowią fragmentów nadrzędnej całości - trudno im odmówić rozpoznawalnej wspólnoty, będącej efektem

9 L. Hill Maurice Blanchot and Fragmentary Writing..., s. 217. 
przewijających się motywów: śmierci, innego, pisania, neuter, fragmentu, fragmentaryczności.

Mechanizmem fragmentarycznego jest „przerywanie”10, nagła i niespodziewana, wspomagana bielą papieru, interwencja nieobecności - braku kontynuacji myśli, związku z kolejnym lub poprzedzającym fragmentem, ciągłości narracyjnej lub dialogicznej - która jednak przywołuje niedookreślone quasi-obecności: mniej lub bardziej nieuchwytne związki z innymi fragmentami, konteksty filozoficzne, potencjalne i nieprzewidywalne sensy i epifanie przywoływane niekiedy jednym, zawieszonym jakby w próżni zdaniem lub równoważnikiem zdania:

- Na granicy pisania, zawsze musząc żyć bez ciebie. (SNB, 7)

- Spokojne stowo, niosace strach. $(\mathrm{SNB}, 13)$

- Przeszłość została napisana, przyszłość będzie czytana. Można by to wyrazić w tej formie: to, co zostało napisane w przeszłości, będzie czytane w przyszłości, bez jakiejkolwiek związku z teraźniejszością zdolną ustanowić się między pisaniem i czytaniem. (SNB, 30)

- Lekceważenie lub drwiny: stucha ciszy stowami. (SNB, 68)

- Dziękujęciza wszystkie testowa, które nie zostaty wypowiedziane. (SNB,100)

- Umrzeć zbyt lekko, lizej niż jakakolwiek fantazja w swej fantazmatycznej ciężkości. (SNB, 110).

Niby wyrwane z kontekstu, fragmenty takie przywołują jednak nieprzeniknione konteksty, bez początku i końca, zapraszając równie niezliczone końce i początki.

W stosunku do siebie fragmenty te pozostają w neutralnej, „nijakiej” relacji pozbawionej zasady centrum, przewagi, hierarchii ważności, dominacji. Są "razem i osobno" (SNB, 3), jak wysepki archipelagu "11, wiążą się między sobą wielorakimi ścieżkami, ale też otwierają ścieżki poza siebie, poza własny i wzajemny kontekst, przyzywając, czy to jednym zadziwiającym zdaniem, czy dłuższym fragmentem, kolejne suplementy, niedookreślone i nieobecne, ale też nie-nieobecne. Wędrując przez Le pas au-delà, czytelnik przymuszony

10 Francuskie interruption, które, jak zauważa Christophe Bident, zajmuje w pismach Blanchota miejsce absance. C. Bident The Movements of the Neuter, trans. M. FitzGerald, L. Hill, w: After Blanchot: Literature, Criticism, Philosophy, ed. by L. Hill, B. Nelson, D. Vardoulakis, University of Delaware Press, Newark 2004, s. 23.

11 „Mowa jak archipelag: pocięta na różnorodność swoich wysp i powodująca spiętrzanie wielkiego, otwartego morza; ten starożytny ogrom, nieznane, które ciągle jeszcze ma nadejść, wyznaczone dla nas jedynie przez wynurzanie się nieskończenie podzielonych głębin ziemi" (IC, 309). 
zostaje do „nomadycznej afirmacji” (SNB, 39) - na granicy sensu przemieszcza się przez wysepki archipelagu i sięgać musi poza jego granice, dokąd odsyłają go przerywane fragmenty. Fragmentaryczność, która z założenia wyklucza całość i jedność, nie tyle wymazuje granice własnego pisania, co nigdy ich nie nakreśla, sytuując się w ten sposób poza opozycją wnętrze-zewnętrze, czyniąc pisanie czymś neutralnym wobec niej, czymś zarówno wewnętrznym, jak i zewnętrznym, gdyby użyć idiomu Blanchota. Trzecie neutralność fragmentarycznego - ujawnia się w mowie rozproszonej, ale nie rozłącznej, wielorakiej i jednostkowej jednocześnie.

\section{Czas. Wieczny Powrót. Pisanie. Ślady}

Fragmentaryczne pisanie nie jest jednak mającą epatować idiosynkrazją lub przygodnym wyborem pisarza. „Potrzeba” takiego pisania wynika z ujmowania czasu w perspektywie wiecznego powrotu i powiązania tożsamego - całości i jedności - z teraźniejszością. W aporetycznym rozumieniu Blanchota wieczny powrót łączy w sobie skończoność i nieskończoność, w której brak jest teraźniejszości. Jak zauważa Lycette Nelson, „niemożliwość pomyślenia Wiecznego Powrotu wynika z konieczności myślenia o czasie jako jednocześnie skończonym i nieskończonym, by móc go pomyśleć"12. Wieczny powrót nie mówi „naszym” językiem, w którym, myśląc o czasie, myślimy o przyszłości, teraźniejszości i przeszłości; mówi raczej „milczącym językiem” szaleństwa Nietzschego „dalekim od zwyczajnych form temporalności” (SNB, 40). To, co powraca, a raczej powróci w przyszłości, to nie tożsame wydarzające się w jakiejś teraźniejszości (teraźniejszości jako warunku możliwości tożsamego), ale to, co wydarzyło się w przeszłości bez jakiegokolwiek zapośredniczenia teraźniejszością:

Niech będzie przeszłość, niech będzie przyszłość, bez niczego, co umożliwiałoby przejście od jednej do drugiej, w ten sposób, że linia oznaczająca odgraniczenie tym bardziej by je od-znaczała [unmark], im bardziej pozostawałaby niewidoczna. [...] Prawo powrotu zakładające, iż wszystko miałoby nadejść ponownie, wydaje się ujmować czas jako ukończony [completed]: krąg poza krążeniem wszelkich kręgów; ale o tyle o ile przerywa on pierścień w jego środku, to proponuje czas nie nieukończony [not uncompleted], a przeciwnie, skończony [finite], z wyjątkiem 
teraźniejszego punktu, który w naszym mniemaniu jest jedynym, jaki zajmujemy, a ponieważ go nie ma, ten brak wprowadza w nieskończoność pęknięcie [rupture], powodując, że żyjemy w stanie permanentnej śmierci. $(\mathrm{SNB}, 12)$

Nie można zatem w przypadku wiecznego powrotu myśleć o teraźniejszości jako wszechogarniającej wieczności, w której mieszczą się przeszłość i przyszłość,jedna powtarzająca drugą. Jak wielokrotnie powtarza to Blanchot w Le pas au-delà, myślenie w kategoriach wiecznego powrotu - a myślenie to dominuje w całej książce - wyklucza także obecność teraźniejszości jako czegoś, co przechodzi w przeszłość:

Wieczny Powrót, afirmując przyszłość i przeszłość jako jedyne czasowe autorytety, autorytety identyczne i niepowiązane, uwalniając przyszłość od wszelkiej teraźniejszości [present] i przeszłość od wszelkiej teraźniejszości/obecności [presence], druzgocze myśl i wiedzie do takiego oto stwierdzenia: w przyszłości powracać będzie nieskończenie to, co w żadnej formie i nigdy nie mogło być teraźniejsze [present], w ten sam sposób, jak w przeszłości powróciło to, co - w przeszłości - nigdy w żadnej formie nie należało do teraźniejszości [present]. (SNB, 22)

Między przeszłością, przyszłością, największa różnica polega na tym, że jedna miałaby powtórzyć drugą bez wspólnej miary teraźniejszości: jak gdyby między przeszłością i przyszłością nieobecność teraźniejszości rządziła w uproszczonej formie zapomnienia.

Co powróci? Wszystko, z wyjątkiem teraźniejszości [present], możliwości teraźniejszości/obecności [presence]. $(\mathrm{SNB}, 16)$

Wiara, że mogłaby istnieć jakaś teraźniejszość, która by przeminęła, stając się przeszłością, jest jedynie „iluzją” (SNB, 13). Odrzucenie tej iluzji ma dalekosiężne skutki, zważywszy leksykalną bliskość teraźniejszości i obecności w języku francuskim (i angielskim): presence może znaczyć zarówno teraźniejszość, jak i obecność. W tej swoistej grze słowa nieistnienie teraźniejszości implikuje także brak obecności: „Teraźniejszości brakuje obecności, ona niszczy teraźniejsze obecności"13. Zamiast wiecznej obecności teraźniejszości mamy w tym myśleniu nieskończony powrót czasowego pęknięcia,

13 "Presence lacks presence, destroys the present of presence" (SNB, 81). 
przerwania czy rozłamu [rupture]: „Myśl, że wszystko powraca, myśli czas w jego niweczeniu, ale przez to niweczenie, które wydaje się redukować go do dwóch czasowych zjawisk [instances], myśli go jako nieskończony, nieskończoność pęknięcia lub przerwania zastępująca obecną [teraźniejszą, present] wieczność nieskończoną nieobecnością" (SNB, 23).

Myśl, jaka nieodparcie się nasuwa sugeruje, że pęknięcie jest naturalną przestrzenią Trzeciego, neutralnego, neuter, i tak też wydaje się sądzić Blanchot, próbując odpowiedzieć na pytanie, co powraca, jeżeli „powraca wszystko” pytanie, któremu poświęca wiele miejsca w L'Entretien infini. Ostatecznie jednak odpowiada na to pytanie swym własnym pytaniem, które wszelako ma charakter niemal twierdzenia: „Czyż nie jest zatem tak, iż nic z tego tożsamego [same] nie powraca do tożsamego, z wyjątkiem samego powrotu [...]; i czyż nie jest tak, że afirmacja powrotu nie prowadzi do wspólnej afirmacji - ale bez konstytuowania całości - różnicy i powtórzenia, a więc 'nie-tożsamości tożsamego' [non-identity of the same]?" (IC, 275). W wiecznym powrocie nie powraca zatem ani tożsame, ani Jednia, ani Całość, a powraca sam powrót pod postacią neutralnego: „to powraca, powrót powraca (jako neutralne)” (IC, 275).

Nieskończone pęknięcie, w którym pojawia się neuter, jest też przestrzenią i czasem pisania, ale pisania rozumianego w sposób specyficzny - jako „odzewu na afirmację powrotu” (SNB, 55). „Potrzeba” pisania, o której wielokrotnie wspomina Blanchot, wynika z tego, że to właśnie w pisaniu wieczny powrót może się potwierdzić (SNB, 55). W czasie pozbawionym teraźniejszości, zdaje się mówić Blanchot, nie ma miejsca na myśl podporządkowaną racjonalności logosu opierającego się na autorytecie całości, tożsamości i jedności, i stąd wynika potrzeba myśli fragmentarycznej, wykluczającej całość jako spoiwo: „Fragmentaryczne nie poprzedza całości, ale wyraża się poza całością i po niej” (IC, 152). W takim w pisaniu - siedlisku aporii rojącym się od nierozwiązywalnych antynomii - wieczny powrót najlepiej się przejawia: „Potrzeba powrotu byłaby zatem potrzebą czasu bez teraźniejszości, czasu, który byłby także czasem pisania, czasem przyszłym, czasem przeszłym, których radykalne rozdzielenie (przy nieobecności teraźniejszości), nawet jeśli obydwa są tożsame, powstrzymuje nas od określenia ich inaczej niż jako różnicę, którą niesie powtórzenie" (SNB, 16).

Czas bez teraźniejszości jest zatem czasem pisania, budzi „potrzebę pisania"14, ale pisania rozumianego nie jako zapis mowy, wtórny wobec niej,

14 Nie miejsce tu, by tę zależność omawiać, ale należy zwrócić uwagę na analogię między pisaniem i umieraniem w czasie bez teraźniejszości, którą Blanchot kilkakrotnie przywołuje: „[...] pisanie, 
a jako ustawiczne rozpoczynanie, które jednocześnie rozpoczynaniem nie jest, jest bowiem powtarzaniem - powtarzaniem jednak nie tożsamego, ale różnicy: „różnicy] utrzymywanej przez samo właśnie powtórzenie, którego możliwość umyka, bo jest przekazana różnicy, która w sposób konieczny zawsze się już powtarzała, chociaż zawsze będzie się powtarzać, bez możliwości wypowiedzenia jej w taki sposób, by powtarzała się w teraźniejszości [present]" (SNB, 57). Pisanie jednak, nawet jeżeli nie jest wtórne wobec mowy, to i tak zawsze jest wtórne, zawsze „jest drugie", bo chociaż nic go nie poprzedza, to ono samo nie pretenduje do pozycji pierwszego, „niwecząc w zamian wszelkie pierwszeństwo przez swe nieokreślone odniesienie, które nie pozostawia miejsca nawet dla pustki" (SNB, 90). W czasie wiecznego powrotu pisanie jest raczej prze-pisywaniem, ale rozumianym nietrywialnie, bez poprzedzającego wzorca czy oryginału:

Przepisywanie, podwajanie, które zawsze poprzedza lub zawiesza jedność od-znaczając ją: przepisywanie trzyma się z dala od wszelkich produktywnych inicjatyw i nie twierdzi, że coś wytwarza, nawet nie przeszłość lub przyszłość lub teraźniejszość pisania. Przepisywanie, powtarzając to, co się nie wydarza, nie będzie wydarzać, nie wydarzyło, wpisuje się w nieujednolicony system relacji, które krzyżują swe drogi bez jakiegokolwiek punktu przecięcia potwierdzającego ich zbieżność, wpisuje się w potrzebę powrotu, przez który zostajemy wyrwani z trybów czasowości zawsze mierzonych jednością teraźniejszości [obecności, presence]. (SNB, 32)

W tym ujęciu wiecznego powrotu niemożliwość teraźniejszości wyklucza pierwotną, początkową obecność, która odnajdowałaby się w powtórzeniach, kolejnych powrotach. Jedyną quasi-obecnością dostępną pisaniu - słyszymy tu echa Jacques'a Derridy - są ślady, same pozbawione pierwowzoru, którego śladami miałyby być: „A ślad, zawsze będący śladami, nie odnosi się do żadnej początkowej obecności, która nadal byłaby obecna jako reszta lub pozostałość

umieranie są słowami, którym byłoby blisko do siebie" (SNB, 89). "«Być może znów w zgodzie z potrzebą powrotu: to zawsze będzie miało miejsce, ponieważ to zawsze już miało miejsce». «lak gdyby umieranie pozwalało nam w pewien sposób żyć w wiecznej okrężnej drodze przeszłości i w wiecznej okrężnej drodze przyszłości, których nie zjednoczyłaby żadna teraźniejszość». [...] nie ma teraźniejszości dla umierania" (SNB, 107). [...] można powiedzieć, że książka jest tym dla pisania, czym śmierć byłaby dla ruchu umierania; można powiedzieć, że pisanie, umieranie są tym, co jest najbardziej dyskretne, chociaż zawsze czynione jawnym przez Ostatni Akt, wielką jak grobowiec skałą Księgi, suwerenną publikację nieobecnej obecności" (SNB, 104). 
tam, gdzie zniknęła" (SNB, 54), pisze Blanchot. Czytelnikowi mogłoby się zdawać, że dotarł już do sedna pisania/prze-pisywania, ale to pozór jedynie, amfilada aporii otwiera przed nim kolejne drzwi: „Pisaniu nie jest przeznaczone pozostawianie śladów, a wymazywanie, przez ślady, wszystkich śladów, znikanie we fragmentarycznej przestrzeni pisania bardziej definitywnie niż znika się w grobowcu" (SNB, 50). Pisanie tworzy ślady nieznające oryginału, ale jednocześnie - i tutaj Blanchot idzie dalej niż Derrida w dekonstrukcji obecności - te ślady wymazuje, a w istocie wymazuje je wcześniej, niż tworzy: „Wymazane zanim napisane” (SNB, 17). Zgodnie z „nieskończoną potrzebą wymazywania” („Wszystko musi się wymazać, wszystko się wymaże” (SNB, 53), aporetyczne pisanie, któremu nie jest przeznaczone pozostawianie śladów, tworzy jednak te ślady - ślady bez pierwotnego źródła, powtarzane, ale nigdy nie tożsame, naznaczone różnicą powrotu - po to tylko by jednocześnie je wymazać:

pisać to poruszać się w świecie śladów ku wymazaniu śladów i wszystkich śladów, ponieważ ślady są przeciwieństwem totalności i zawsze już się rozpraszają. [...] nie mają początku, ale mają koniec w samej tej trwałości, która wydaje się je zachowywać, ślady, które nawet, gdy gmatwają się i zastępują jeden drugi, są tam na zawsze, na zawsze odcięte od tego, czego miałyby być śladami, nie mając żadnego istnienia poza swoją wielością, jak gdyby nie było śladu, ale ślady, nigdy te same i zawsze powtórzone. [...] zawsze mnożą się i nakładają na siebie, ślady na ślady, nie po to, by być odczytanym, ale by wymazać się w wielości. (SNB, 53-54)

\section{Wymazanie podmiotu}

Wymazywanie obejmuje nie tylko ślady pisania, ale także wszelką tożsamość, w tym i tego, który pisze: „Pisać: działanie nieobecności działania, produkcja, która nie produkuje nic poza nieobecnością podmiotu [...]" (SNB, 55). W czasie bez teraźniejszości i pełni obecności, w czasie wiecznego powrotu, w którym „przyszłość jest zawsze już przeszła a przeszłość zawsze dopiero nadejdzie”, wykluczający się moment teraźniejszości jednocześnie „wyklucza jakąkolwiek możliwość tożsamości" (SNB, 11). Dotyczy to tożsamego w najszerszym znaczeniu, ale przede wszystkim dotyczy to jaźni i podmiotu, dla których osadzenie w teraźniejszości jest nieodzowne: ja jako tożsame jawi się sobie jako obecne tu (miejsce) i teraz (teraźniejszość): „«Ja» wymaga bycia tam, zdecydowanej obecności [...] Ktokolwiek mówi «ja», ciągle mówi 
obecność" (SNB, 71). Obecność wymaga teraźniejszości, gdy tymczasem ta została usunięta przez prawo wiecznego powrotu. W krótkim fragmencie Le pas au-delà nieokreślony nadawca (ten, kto pisze? uczestnik dialogu?) zwraca się, ostrzegając, do nieokreślonego adresata: „prawo powrotu, określające całą przeszłość i całą przyszłość, nigdy nie pozwoli ci, chyba że przez nieporozumienie, na pozostawienie dla siebie miejsca w możliwej teraźniejszości [present] ani nie pozwoli jakiejkolwiek teraźniejszości/obecności [presence] zbliżyć się do ciebie" (SNB, 11). W kolejnym fragmencie mówca zwraca się już do siebie, do własnej aporetyczności, która sytuuje go poza sobą: „Wieczny Powrót Tożsamego: tożsamego, to znaczy mnie, w stopniu jakim ja podsumowuje regułę tożsamości, to znaczy obecną/teraźniejszą [present] jaźń. Ale potrzeba powrotu, wykluczając z czasu jakikolwiek tryb teraźniejszy, nigdy nie wyzwoliłaby jakiegoś teraz, w którym tożsame powróciłoby do tożsamego, do mnie" (SNB, 11). Jaźń w czasie wiecznego powrotu to jaźń rozdygotana, niepewna siebie, która niby istnieje, ale istnieje raczej w swym zanikaniu, w tym, co jest tylko „inercją jaźni, która unicestwia się i utrzymuje się w swej klęsce” (SNB, 128). W rezultacie słowo „ja" - które wielokrotnie pojawia się na kartach Le pas au-delà - przestaje być koherentną obecnością, a staje się jedynie „kanonicznym skrótem reprezentującym prawo tożsamego” (SNB, 6) i w pęknięciu między przeszłością i przyszłością ustępuje neuter, które nie potrzebuje teraźniejszości ani miejsca.

„Potrzeba pisania”, pisanie - czynność, która w Le pas au-delà jawi się paradoksalnie jako sposób egzystencji - nie może spełnić nadziei zjednoczenia tej egzystencji w jedność i nadania jej koherencji; przeciwnie, pisanie pozbawia jedności. Poddanie się „potrzebie pisania” równoznaczne jest z przyjęciem zaproszenia do wymazania siebie jako podmiotu pisania: „«Wejdź w destrukcyjny element» - nie piszemy ani jednego słowa, które nie zawierałoby tego zaproszenia [...]" (SNB, 67). Pisanie, powiada Blanchot, odmawia nam relacji do bytu - „rozumianego przede wszystkim jako tradycja, porządek, pewność, prawda, każda forma zakorzenienia" (SNB, 2) - który nazywamy "Jaźnią" lub podmiotem. Ci, którzy „niosą" potrzebę pisania, którzy zostają przez nią porwani, ostatecznie w niej zanikają. Wprawdzie gdzieś w momencie początkowym potrzebne jest jakieś ,ja”, ja „zdolne tam być jedynie po to, by powiedzieć «ja»", ale na tym kończy się jego zadanie ustanowienia „reguły tożsamości" (SNB, 20).

Tekst Le pas au-delà nie tylko mówi o wymazaniu podmiotu, ale jego „pisanie" samo jest ilustracją tego procesu. Już w jednym z początkowych fragmentów książki piszące „ja” wyzbywa się siebie, oddziela się od siebie i staje się 
„nim” („Spróbuję na próżno przedstawić go sobie, jego, którym ja nie byłem, i który, nie chcąc tego, zaczął pisać [...]; SNB, 2). Ale i „on”, pisząc, wyzbywa się podmiotowej tożsamości, którą musi „ująć w nawias":

Pewność, że w pisaniu ujmował w nawias dokładnie tę pewność, włączając w to pewność siebie samego jako podmiotu pisania, doprowadziła go powoli, choć natychmiast, do pustej przestrzeni, której otchłań [...] w żadnej mierze nie zapobiegała zwrotom i okrężnym drogom długiego procesu. $(\mathrm{SNB}, 2)$

W procesie tym „on" ustępuje nijakiemu, neutralnemu „to”, Trzeciemu między i ponad dwoma zaimkami, które jako neuter przejmuje ów proces pisania, usuwając "ja” w sferę hipostazy. "Ja" przyjmuje pewną formę utrwalenia w postaci „fikcyjnej lub funkcjonalnej tożsamości” po to jedynie, by "gra pisania mogła zostać odegrana" (SNB, 4). Jaźń nie jest zatem osobową tożsamością, a „kanonicznym skrótem” lub inaczej „formułą która reguluje [...] i obdarza błogosławieństwem, w pierwszej osobie, pretensje Tożsamego do supremacji" (SNB, 4), podobnie jak kanonicznym skrótem reprezentującym prawo tożsamego jest owo hipotetyczne, fikcyjne „ja”. Ale i samo „to”, le „ „l" - „partner” w grze pisania i jej wytwór - nie posiada stabilnej obecności: jako główny gracz „zmienia się, przemiejscawia się i zajmuje miejsce samej zmiany - przemiejscowienie, któremu brak umiejscowienia, i którego nie ma w żadnym umiejscowieniu"15 (SNB, 4).

Ta redukcja i destrukcja ,ja" potwierdza się we fragmentach narracyjnych i dialogicznych. Zdania fragmentów mają swoje podmioty gramatyczne - bez imion własnych, przeważnie w trzeciej osobie liczby pojedynczej lub mnogiej - jednak niemożliwość rozpoznania i utożsamienia tych podmiotów, ich nieprzypisywalność do postaci i osobowa "neutralność" prowadzi do wymazania podmiotu jako tożsamości i zastąpienia go przez bezosobowy neuter: „Na razie jedyna rzecz, którą można powiedzieć: to, o jedno słowo za wiele, które podstępnie umieszczamy na granicy pisania lub relacji pisania do pisania, gdy pisanie wskazuje na siebie jako swą własną granicę" (SNB, 6). Pojawiające się ze swoistym rytmem w tekście stwierdzenie nieokreślonej osoby, mówiącej „nie wiem, ale mam poczucie, że będę wiedział w przeszłości”"16,

15 „Player [...] changes, displaces itself and takes the place of the change itself, displacement that lacks placing and that is missing from any placing" $(\mathrm{SNB}, 4)$

16 "I don't know, but I have the feeling that I'm going to have known"(np. SNB, 112). 
w jednym z fragmentów przybiera postać dramatycznego wyznania zanikającego podmiotu:

- Nie wiem; nie ma 'ja', które mogłoby wiedzieć. (SNB, 68)

Enigmatyczne postaci zamieszkujące kursywę zdają się doświadczać podobnego zanikania tożsamości: „On już sięnie wyodrębnia, on się rozpada” (SNB, 65); "Jest we mnie ktoś, kto nie czyni nic innego oprócz niweczenia tego mnie: nieskończone zajęcie" (SNB, 66). Podobnie, jak jedna z osób w opowieści pisanej kursywą rozmywa się w języku (Nie jestem panem języka. Stucham go jedynie w jego wymazaniu, w nim się wymazując [...]; SNB, 30), tak w pisaniu rozmywa się, wymazuje i zanika podmiot.

Pozbawione podmiotu pisanie jest pisaniem anonimowym, co nie znaczy, że nie jest oznaczone imieniem: "nigdy nie uwolnimy się od imienia” (SNB, 37). Anonimowość nie odmawia imienia („Anonimowość jest nam dana w samym imieniu”, SNB, 37), pozostawia je na miejscu, ale czyni je „pustym”, ponieważ „imię nie daje imienia, ale jest nie-jednością i nie-obecnością bezimiennego" (SNB, 35). Miejsce desygnatu imienia zajmuje neuter, to, wprawdzie też „bez miejsca”, bez obecności lub nieobecności, „które mogłyby je potwierdzić", ale jednak na swój Trzeci sposób obecne między słowami: "Anonimowość jest niesiona przez to, które zawsze wymawia imię zawczasu zapomniane” (SNB, 35). Choć pojawia się pokusa, by „nazwać je, przypisując sobie”, to jednak to, co anonimowe wymawiane jest zawsze „tylko w trzeciej osobie i w neuter" (SNB, 98).

"To" - neuter, „nieokreślony element”, , substytut substytutu”, ,zaimek nie wskazujący niczego poza pustką", nie zajmuje jednak miejsca zwolnionego przez jaźń, „nieupodmiotowiony podmiot” (SNB, 5), ale też nie pozostawia go próżnym. Jako Trzecie sytuuje się "między-dwoma, gdzie się rozprasza” (SNB, 35), między obecnością a nieobecnością - „nie-obecne i nie-nieobecne",,,to [le 'il'] bez tożsamości; osobowe? bezosobowe? jeszcze nie i zawsze już poza" (SNB, 6). Najtrudniejszą rzeczą, pisze Blanchot (zapewne z perspektywy „naszej” teraźniejszości), jest powstrzymanie się przed próbą zatrzymania tego ,jak gdyby było tożsame i zawsze w miejscu, w który którym ktoś zdecydował się je uchwycić” (SNB, 20). To, nawet w najprostszym zdaniu, „pozostaje nieco poza zdaniem" zwolnione „z roli podmiotu, którą zdaje się przyjmować" $(\mathrm{SNB}, 11)$. Wymazawszy jednak podmiot, to wymazuje też siebie „w neutralności pisania” (SNB, 6), usuwa się „ze swej rangi i roli podmiotu” (SNB, 59). Pisanie w istocie uwalnia się od jaźni, od podmiotu rozumianego jako byt 
koherentny; w pewnym sensie pisanie pisze się samo ${ }^{17} \mathrm{i}$ „zawsze będzie się pisać od nowa” (SNB, 55). Pozostając w aporii Trzeciego, pisanie „nic nie stwierdza, ono tylko pisze, a nawet nie pisze" (SNB, 104). Podmiot w sensie spójnej tożsamości został wymazany i zastąpiony przez neutralne Trzecie to - usytuowane „na granicy pisania”.W konsekwencji Trzeciość neutralnego przesyca pozbawione podmiotu samo pisanie, a raczej samo-pisanie.

Trzeciość neuter przesyca także pisanie Blanchota. Sprzeczności i aporie tego pisania przypominają niekiedy dyskurs Hegla, jednak zdają się one sytuować poza jakąkolwiek dialektyką zmierzającą ku syntezie; przeciwnie, prowadzą do redukcji i zneutralizowania własnego znaczenia, ale w tej redukcji/neutralizacji wyłania się znaczenie nowe - jakby poza słownikowym znaczeniem słów - nieokreślone i bardziej doświadczane niż rozumiane, doświadczenie rozumiejące poza rozumieniem zwykłej semantyki słów. Tę Trzeciość neutralnego wykraczającą poza czytelne opozycje, trafnie ujmuje Christopher Bident:

Jeżeli neuter jest nieredukowalne do tego, co jasne lub niejasne, to przede wszystkim dlatego, iż jest nieredukowalne do siebie samego: szeroko niezdefiniowane, nie przedstawia się jako koncept, który jest jasny lub który wyjaśnia, lub który jest źródłem wyjaśnienia, albo taki, który działa lub jest skuteczny; migrując niecierpliwie od literatury do filozofii, od filozofii do literatury, ostatecznie nie jest być może ani konceptem ani perceptem $^{18}$ : ani tym ani tamtym. ${ }^{19}$

Ale nie tylko o jedno pojęcie (koncept lub precept) tu chodzi. Winniśmy w tym miejscu dostrzec filozoficzny wysiłek Blanchota skierowany przeciwko "całej historii filozofii", która jego zdaniem nieustannie wykluczała neuter „z naszych języków i z naszych prawd”, a czyniła to, albo zastępując neuter bezosobowymi „rządami uniwersalności”, albo też, przeciwnie, podważała go

17 Por.: „Książki wydają się istnieć po to, by zachować pisanie i pozwolić mu ustanowić się w jego własnej przestrzeni, w sposób oddzielny i jak gdyby oddzielony od jakiegokolwiek życia" (SNB, 56). "[...] pisanie pisze się jedynie na granicy pisania, tam, gdzie książka, chociaż nadal tam obecna, jest presją końca (bez końca) książek” (SNB, 57). „To, co pisanie zdradza, to nie to, co pisanie miałoby przepisywać, a co nie mogłoby być przepisane, a samo pisanie, które, zdradzone, odwołuje się do śmiechu, do łez, do pasywnej niepasywności, starając się pisać bardziej pasywnie niż jakakolwiek pasywność" (SNB, 116). 
ustanowieniem „etycznej supremacji Jaźni-Podmiotu, mistycznego dążenia do jednego Jedynego" (IC, 299).

Trzecie jako neuter sięga ontologicznych głębi; „w pewnym sensie” poprzedza Heideggerowskie Bycie i neutralizuje je: „neutralne tego, co nazywamy byciem $^{20}$, które umieszcza bycie w nawiasie i w pewnym sensie poprzedza je, zawsze już neutralizowało je, mniej przez działanie unicestwiające niż przez działanie nie-działające" (IC, 303). Pozornie można by dostrzec w Sein, pisze Blanchot „fundamentalne słowo dla neuter lub neutralnego" (IC, 458), ale natychmiast przychodzi nam skorygować tę opinię, mimo że Sein zdaje się wzywać do myślenia neutralnym. Fakt, że Bycie „rozświetla się, otwiera i przejawia w bytach, które stają się otwarciem jasności", powoduje, że relacja Sein do prawdy jest „zasłoną odsłaniającą się w obecności światta” (IC, 458), gdy zaś neutralne wiąże się z nieznanym i pozostaje od Bycia niezależne: „suwerenność neutralnego, zawsze w nadmiarze wobec Bycia, opróżniona ze znaczenia i przez tę próżnię absolutnie oddzielna od wszelkiego znaczenia i nie-znaczenia" (IC, 304). Neuter w istocie więc nie poprzedza Bycia (SNB, 76) lub poprzedza je tylko „w pewnym sensie", nie tylko sytuując się między Byciem a bytami („raczej w ponad nimi lub w tutaj między-nimi”; SNB, 76), ale też wymykając się samemu Byciu, „neutralizując je do punktu, w którym uniemożliwia mu nazwanie go byciem neutralnego" (SNB, 76). Suwerenność neuter jako Trzeciego, inaczej niż chora, nie leży jedynie u podstaw ontologii, ale ją podważa, podobnie jak podważa myślenie w kategoriach jedności i dwoistości. 


\section{Abstract}

\section{Wojciech Kalaga}

UNIVERSITY OF SILESIA (KATOWICE)

Blanchot: The Third amongst Pronouns

The paper is concerned with the negation of dichotomous and totalizing thinking in the work of Maurice Blanchot from the standpoint of the category of the Third. Kalaga proposes a close reading of Blanchot's texts to analyse concepts such as neuter, the unknown, the fragmentary as well as writing and trace in Blanchot's version of the Eternal Return. These concepts evade the binary logic of the Western logos, while the very act of writing - viewed from their perspective - eventually leads to the erasure of the self and the subject.

\section{Keywords}

Blanchot, the Third, binarism, neuter, subject 